AT-TAJDID: Jurnal Pendidikan Dan Pemikiran Islam

(p-ISSN: 2548-5784 |e-ISSN: 2549-2101)

Vol. (4)(02), (Juli-Desember)(2020), (Halaman)(178-190)

Doi: http://dx.doi.org/10.24127/att.v4i02.1464

\title{
NURCHOLISH MADJID (1939-2005) \\ (Gagasan-Gagasan Pembaruan Pemikiran Islam Kontemporer di Indonesia)
}

\author{
Cahaya Khaeroni $^{\mathbf{1}}$ \\ Universitas Muhammadiyah Metro \\ C.Khaeroni@gmail.com
}

\begin{abstract}
ABSTRAK
Nurcholish Madjid merupakan salah satu tokoh pembaruan pemikiran Islam di Indonesia. Lewat gagasannya tentang teologi Islam Inklusif dan sekularisasi yang dipopulerkannya pada era 1970-an, Nurcholish Madjid tampil menjadi sosok intelektual dan pembaharu yang berdiri di garda depan dalam kancah pemikiran Islam di-Indonesia. Kendatipun demikian, juga tidak dapat dipungkiri bahwa pemikiran-pemikiran yang dilontarkannya juga kerap memunculkan polemik-polemik mendalam diantara banyak kalangan elit intelektual Muslim. Menanggapi hal inilah, penelitian ini berusaha mengkaji lebih lanjut mengenai pemikiran-pemikiran Nurcholish Madjid, seorang tokoh pembaharu kontemporer yang cukup kontroversial baik dikalangan masyarakat awam maupun elit intelektual di Indonesia. Penelitian ini termasuk ke dalam jenis penelitian kualitatif dengan menggunakan pendekatan filosofis. Karakteristik dari pendekatan ini lebih menekankan pada fundamental structure dan ide-ide dasar serta menghindarkan detail-detail persoalan yang kurang relevan. Hasil penelitian menyimpulkan bahwa pemikiran pembaharuan Nurcholish Madjid terbagi ke dalam 3 wilayah: Pertama, gagasan Modernisasi Islam; Kedua, Sekularisasi; dan ketiga, gagasan teologi inklusif.
\end{abstract}

Kata kunci: Nurcholish Madjid, Pembaharuan pemikiran Islam

\begin{abstract}
Nurcholish Madjid is one of the leaders in the reform of Islamic thought in Indonesia. Through his ideas about Inclusive Islamic theology and secularization which he popularized in the 1970s, Nurcholish Madjid appeared to be an intellectual and reformer who stood at the forefront of Islamic thought in Indonesia. However, it is also undeniable that the thoughts he expresses often lead to deep polemics among many of the Muslim intellectual elite. In response to this, this research seeks to further examine the thoughts of Nurcholish Madjid, a contemporary reformist figure who is quite controversial among both the lay community and the intellectual elite in Indonesia. This research belongs to the type of qualitative research using a philosophical approach. The characteristic of this approach emphasizes more on the fundamental structure and basic ideas and avoids the details of the problem that are less relevant. The results of the study concluded that Nurcholish Madjid's thought of renewal was divided into 3 areas: First, the idea of Islamic Modernization; Second, Secularization; and third, the idea of inclusive theology.

Reform of Islamic thought
\end{abstract}

Keyword: Nurcholish Madjid, Pembaharuan pemikiran Islam 
AT-TAJDID: Jurnal Pendidikan Dan Pemikiran Islam

(p-ISSN: 2548-5784 le-ISSN: 2549-2101)

Vol. (4)(02), (Juli-Desember)(2020), (Halaman)(178-190)

Doi: http://dx.doi.org/10.24127/att.v4i02.1464

\section{A. PENDAhuluan}

Membincangkan sosok Nurcholish Madjid memang tiada kata henti, pesona dan kharisma tokoh asal Jombang ini memang sangat luar biasa, beliau juga dianggap sebagai salah seorang tokoh pembaruan pemikiran Islam di Indonesia. Lewat gagasannya tentang teologi Islam Inklusif dan sekularisasi yang dipopulerkannya pada era 1970-an, Nurcholish Madjid tampil menjadi sosok intelektual dan pembaharu yang berdiri di garda depan dalam kancah pemikiran Islam di-Indonesia. Kendatipun begitu, juga tidak dapat dipungkiri bahwa pemikiran-pemikiran yang dilontarkannya juga memunculkan polemik-polemik mendalam diantara banyak kalangan elit intelektual Muslim.

Sekitar era 1970-an, gagasan yang dikemukakan Cak Nur (Sapaan akrab Nurcholish Madjid) memang benar-benar sempat menggegerkan jagat pemikiran Islam di Indonesia. Dia menggagas tentang pentingnya sekularisasi, sehingga Muhammad Kamal Hassan pun menipologikannya sebagai "ModernisSekuler". Tidak berhenti disitu, cak Nur juga menerjemahkan ungkapan syahadatyang diyakini umat Muslim sebagai rukun Islam pertama - dengan terjemahan: "Tiada tuhan selain Tuhan." Dalam hal ini, khususnya kelompok Islam skripturalis pun menganggap hal tersebut sebagai "Kejahatan" intelektual dan menyelewengkan makna Islam. Dan sejak itu pulalah, sosok Nurcholish Madjid semakin dikenal luas di kalangan masyarakat umum dan terlebih lagi di kalangan elit intelektual Muslim di Indonesia.

Berbeda dengan sosok intelektual Islam lain, semacam Abdurrahman Wahid yang cenderung memilih segmen populis dalam mengartikulasikan gagasan-gagasannya. Cak Nur justru mengambil wilayah segmen elitis dalam melontarkan gagasangagasan cerdasnya, sebab beliau menyadari betul bahwa itulah cara yang harus ditempuhnya. Jika beliau menulis, maka akan dijumpai sekian banyak referensi yang digunakan untuk menguatkan pendapatnya. Hal ini bukan berarti beliau tidak yakin akan kebenaran pikirannya, namun begitulah cara cak Nur dalam meyakinkan banyak orang tentang kebenaran yang diusungnya. Sehingga wajar saja ketika beliau berpidato di Taman Ismail Marzuki, 3 Januari 1970, dengan tema "Keharusan Pembaharuan Pemikiran Islam dan Masalah Integrasi Umat" maka dapatlah dijumpai tulisannya tersebut sangat penuh dengan referensireferensi berbobot. Dan hal itu yang terusmenerus dikembangkan sampai akhir hayatnya. Oleh karena itu, dapat disimpulkan akan adanya kecenderungan elitis yang tampak dalam karya-karyanya.

Sementara itu, dimata para pengamat perkembangan pemikiran Islam, sosok Nurcholish mereka tempatkan di barisan terdepan sebagai pemikir "NeoModernisme Islam." Penguasaan Nurcholish yang luas, baik tentang pemikiran Islam klasik maupun tentang pemikiran Islam modern, telah melengkapi 
AT-TAJDID: Jurnal Pendidikan Dan Pemikiran Islam

(p-ISSN: 2548-5784 le-ISSN: 2549-2101)

Vol. (4)(02), (Juli-Desember)(2020), (Halaman)(178-190)

Doi: http://dx.doi.org/10.24127/att.v4i02.1464

peralatan intelektualnya untuk ditempatkan di gerbang terdepan sebagai pemikir neo-modernisme Islam. Selain itu, dia juga diapresiasi sebagai peletak dasar neo-sufisme yang menekankan pentingnya aktualisasi etika Islam bagi umat Muslim dalam menggumuli kompleksitas tantangan modernitas.

Disinilah, nampaknya cukup menarik untuk mengkaji lebih lanjut mengenai pemikiran-pemikiran Nurcholish Madjid, sang pembaru kontemporer yang cukup kontroversial baik dikalangan masyarakat awam maupun elit intelektual di Indonesia. Bahkan seorang H.M Rasyidisalah seorang tokoh intelektual tersohor pada waktu itu, menteri agama pertama pada era orde baru dan juga merupakan senior Nurcholish Madjid - juga sempat mengkritik dan menyayangkan gagasangagasan yang dilontarkan oleh Nurcholish Madjid, karena tidak membahas terlebih dahulu dikalangan terbatas elit intelektual. (Rasyidi, 1972).

Hal tersebut menunjukkan akan adanya perdebatan sengit dalam menanggapi pemikiran-pemikiran Nurcholish madjid yang terkesan melawan mainstream pemikiran saat itu, padahal juga perlu diketahui bahwa H.M Rasyidi termasuk juga dalam golongan modernis.

Dalam tulisan ringkas ini penulis berusaha mengerahkan segenap kemampuan penulis untuk mengkaji pemikiran-pemikiran pembaruan Islam Nurcholish Madjid tersebut. Dengan harapan, semoga tulisan ini mampu memberikan kontribusi yang signifikan dalam khazanah keilmuan dan keIslaman di bumi Indonesia tercinta, amin.

\section{B. Metodologi}

Penelitian ini merupakan jenis penelitian kualitatif, yang dapat dikategorikan sebagai penelitian kepustakaan (library research). (Lexy, 2010) Yaitu jenis penelitian yang dilakukan dengan menelaah dan menggunakan bahan-bahan pustaka berupa buku, ensiklopedi, jurnal, majalah, dan sumber pustaka lainnya yang relevan dengan topik atau permasalahan yang dikaji sebagai sumber datanya. (Hadi, 1990).

Adapun pendekatan dalam penelitian ini menggunakan pendekatan filosofis. Karakteristik dari pendekatan ini lebih menekankan pada fundamental structure dan ide-ide dasar serta menghindarkan detail-detail persoalan yang kurang relevan. Karena filsafat memberi banyak kesempatan untuk memikirkan keyakinankeyakinan yang mungkin tidak pernah dipertanyakan, mengapa berpegang kepadanya? Atas dasar apa berpegang kepadanya? Dengan menentang bentukbentuk keyakinan dan asumsi-asumsi itu akan melindungi dari pra-anggapan dan kefanatikan serta meyakinkan diri atas apa yang dipercaya dan mengapa kita mempercayainya (Qodir, 2006). 
AT-TAJDID: Jurnal Pendidikan Dan Pemikiran Islam

(p-ISSN: 2548-5784 le-ISSN: 2549-2101)

Vol. (4)(02), (Juli-Desember)(2020), (Halaman)(178-190)

Doi: http://dx.doi.org/10.24127/att.v4i02.1464

\section{Hasil dan Pembahasan}

Biografi dan riwayat pendidikan Nurcholish Madjid

Nurcholish Madjid lahir di Mojoanyar, Jombang, Jawa Timur, pada tanggal 17 Maret 1939. Ayah Nurcholis, Haji Abdul Madjid, mempunyai hubungan yang baik dan akrab dengan KH Hasyim Asy'ari, pendiri dan pengasuh Pesantren Tebuireng, Jombang (Ismail, 2008). Ketika Masyumi (Majelis Syuro Muslimin Indonesia) dibentuk dan jabatan ketua umumnya dipercayakan kepada $\mathrm{KH}$ Hasyim Asy'ari, Abdul Madjid menyertai Masyumi. Bersama keluarganya, Nurcholis menjalani dan menikmati masa kanak-kanaknya di Jombang. Masa muda Nurcholis banyak dihabiskan di pesantren tempat dia menuntut ilmu. Nurcholis pernah nyantri di Rejoso Pesantren Darul 'ulum (1955), lalu dia melanjutkan pendidikan pesantrennya di pondok Modern Gontor (Ponorogo,1960). Di pondok inilah, dia mulai membangun fondasi dan basis intelektualnya sehingga dia menguasai bahasa Arab dan Inggris. Kemudian Nurcholis Madjid melanjutkan studinya ke Fakultas Adab UIN Syarif Hidayatullah (sebelumnya bernama IAIN) Jakarta, tamat pada tahun 1968 (B.A) dan 1968 (doktorandus). Beliau juga berkesempatan melanjutkan studinya di University of Chicago Amerika serikat sampai memperoleh gelar Ph.D dalam bidang ilmu kalam dan filsafat. Dia menulis disertasi berjudul Ibn Taimiya on Kalam and Falsafah: Problem of Reason and Revelation in Islam di bawah bimbingan Profesor Fazlur Rahman, seorang sarjana Muslim Pakistan, Profesor Fazlur Rahman terkenal sebagai sarjana yang sangat mendalami bidang studi pemikiran Islam yang mengajar di Universitas Chicago saat itu.

Nurcholish, sebagai mahasiswa, tidak saja serius menekuni studinya di fakultasnya, akan tetapi juga terlibat dalam kegiatan-kegiatan kemahasiswaan dan diskusi di luar kampus dan berkecimpung pula dalam berbagai kancah aktivitas ekstra kurikuler. Nurcholis pernah menjadi ketua umum PB HMI (Pengurus Besar Himpunan Mahasiswa Islam) selama dua periode (1967-1969 dan 1969-1971). Antara tahun 1967-1969, dia menjabat sebagai Presiden Persatuan Mahasiswa Islam se-Asia Tenggara (Permiat). Salah satu wakilnya adalah Anwar Ibrahim (yang kemudian menjabat sebagai Deputi Perdana Menteri Malaysia).

Dia menikahi Omi Komariah dan dikaruniai dua orang anak: Nadia dan Ahmad Mikail. Tinggal di Jakarta, keluarga ini hidup berbahagia, rukun dan harmonis menjalani kehidupan rumah tangganya. Nurcholis mempunyai menantu bernama David Bychkon (suami Nadia).

Nurcholish pernah bekerja sebagai peneliti di Lembaga Penelitian Ekonomi dan Sosial (Leknas LIPI, 1978-1984), peneliti senior LIPI (Lembaga Ilmu Pengetahuan Indonesia, 1984-2005), menjadi anggota MPR selama dua periode (10 tahun) di masa pemerintahan orde baru (1987-1992 dan 1992-1997). Dia tercatat pula sebagai pakar dan anggota Dewan 
AT-TAJDID: Jurnal Pendidikan Dan Pemikiran Islam

(p-ISSN: 2548-5784 le-ISSN: 2549-2101)

Vol. (4)(02), (Juli-Desember)(2020), (Halaman)(178-190)

Doi: http://dx.doi.org/10.24127/att.v4i02.1464

Riset Nasional dan dikenal sebagai penggagas pendirian Komite Independen Pemantau Pemilu (KIPP). Karena jasajasanya kepada Negara dan bangsa, dia pada tahun 1998 dianugerahi Bintang Mahaputra oleh Pemerintah Republik Indonesia. (Ismail, 2008).

Dedikasi Nurcholish Madjid yang besar terhadap pengembangan dunia keilmuan, kependidikan dan pembaruan pemikiran dalam Islam telah dia tunjukkan secara konkret dengan mendirikan Yayasan Wakaf Paramadina pada tahun 1986. Dengan mendirikan Yayasan Wakaf Paramadina ini, Nurcholish berupaya untuk mengembangkan dan meningkatkan kualitas kehidupan intelektual Muslim dan untuk lebih mempercepat pembumian gagasan-gagasan pembaruannya. Tujuan pokok Nurcholis madjid adalah untuk menghadirkan sosok Islam sebagai bingkai bangunan spiritual ideal-universal dalam rangka mempertemukan pilar-pilar dimensi transendental agama-agama di tengah-tengah kehidupan masyarakat plural.

Bagi Nurcholish, Paramadina merupakan media untuk membangun suatu tatanan "masyarakat madani" yang mengacu ke masyarakat Madinah yang dibangun oleh Nabi Muhammad saw. Di Paramadina, orang-orang Islam menengah kota berdiskusi tentang masalah-masalah keagamaan dan kekinian. Nurcholish menjadikan Paramadina sebagai tempat untuk mensosialisasikan gagasan dan pemikiran pembaruannya. Pembentukan Paramadina sejalan dengan cita-cita
Nurcholish yang ingin menghadirkan Islam yang bersifat spiritual dan menghadirkannya sebagai spiritual universal untuk mempertemukan dimensi transendental agama-agama (kalimah sawa) di tengah-tengah masyarakat plural. (Ismail, 2008).

Cak Nur meninggal dunia pada 29 Agustus 2005 akibat penyakit sirosis hati yang dideritanya. Ia dimakamkan di Taman Makam Pahlawan Kalibata meskipun merupakan warga sipil karena dianggap telah banyak berjasa kepada negara.

\section{Karya-karya Nurcholish Madjid}

Diantara karya-karya dari Nurcholish Madjid, Antara Lain:

1. Khazanah Intelektual Islam (Jakarta: Bulan Bintang, 1982).

2. Islam Kemoderenan dan Keindonesiaan (Bandung: Mizan, 1987, 1988).

3. Islam Doktrin dan Peradaban, sebuah Telaah Kritis tentang Masalah Keimanan, Kemanusiaun, dan Kemoderenan (Jakarta: Paramadina, 1992).

4. Islam Kerakyatan dan Keindonesiaan (Bandung: Mizan, 1993).

5. Pintu-pintu Menuju Tuhan (Jakarta Paramadina, 1994).

6. Islam Agama Kemanusiaan, Membangun Tradisi dan Visi Baru Islam Indonesia (Jakarta: Paramadina, 1995).

7. Islam Agama Peradaban (Jakarta: Paramadina, 1995). 
AT-TAJDID: Jurnal Pendidikan Dan Pemikiran Islam

(p-ISSN: 2548-5784 le-ISSN: 2549-2101)

Vol. (4)(02), (Juli-Desember)(2020), (Halaman)(178-190)

Doi: http://dx.doi.org/10.24127/att.v4i02.1464

8. Kaki Langit Peradaban Islam (Jakarta: Paramadina, 1997).

9. Tradisi Islam, Peran dan Fungsinya dalam Pembangunan di Indonesia (Jakarta: Paramadina, 1997).

10. Masyarakat Religius (Jakarta Paramadina, 1997).

11. Perjalanan Religius 'Umrah dan Haji (Jakarta: Paramadina, 1997).

12. Bilik-Bilik Pesantren (Jakarta:---). (http://www.doepatu.co.cc/2011/02/ara h-pembaharuan-pemikirannurcholis.html. Di akses pada tanggal 07 Mei 2020)

13. "In Search of Islamic Roots for Modern Pluralism: The Indonesian Experiences" dalam Mark Woodward ed., Toward a new Paradigm, Recent Developments in Indonesian Islamic Thoughts (Tempe, Arizona: Arizona State University, 1996).

14. Dialog Keterbukaan, (Jakarta, Paradima, 1997).

15. Cendekiawan dan Religious Masyarakat, (Jakarta: Paramadina, 1999).

16. Pesan-pesan Takwa (kumpulan khutbah Jumat di Paramadina) (Jakarta:Paramadina, --).

17. The issue of modernization among Muslim in Indonesia, a participant point of view dalam Gloria Davies, ed. What is Modern Indonesia Culture (Athens, Ohio, Ohio University, 1978).

18. "Islam In Indonesia: Challenges and Opportunities" dalam Cyriac K. Pullabilly, (Ed) Islam in Modern
World (Bloomington, Indiana: Crossroads, 1982). http://id.wikipedia.org/wiki/Nurcholis $\underline{\text { h_Madjid) }}$

\section{Ide dan gagasan pembaruan Nurcholish Madjid dalam pemikiran Islam}

Sosok Nurcholish Madjid dapat dikategorisasikan sebagai golongan neomodernis, yakni golongan yang memiliki asumsi dasar bahwa Islam harus dilibatkan ke dalam pergulatan-pergulatan modernisme. Tetapi, dalam rangka untuk mencapai hal tersebut tidak harus mensyaratkan untuk meninggalkan tradisi ke-Islaman yang telah mapan. (Qodir, 2006)

Sebagai sosok pemikir Neo-Modernis, pemikiran pembaruan Nurcholish Madjid setidak-tidaknya dapat di kategorikan dalam beberapa bagian:

\section{Modernisasi}

Modernitas sebagai gerakan pembaharuan yang berawal di Eropa menawarkan cara pandang baru terhadap fenomena kebudayaan. Modernitas muncul sebagai sejarah penaklukan nilai-nilai lama abad pertengahan oleh nilai-nilai baru modernis. Kekuatan rasional digunakan untuk memecahkan segala persoalan kamanusiaan dan menguji kebenaran lain seperti wahyu dan mitos tradisional.

Modernisasi ditandai oleh kreatifitas manusia dalam mengatasi kesulitan hidupnya di dunia. Arnold 
AT-TAJDID: Jurnal Pendidikan Dan Pemikiran Islam (p-ISSN: 2548-5784 le-ISSN: 2549-2101)

Vol. (4)(02), (Juli-Desember)(2020), (Halaman)(178-190)

Doi: http://dx.doi.org/10.24127/att.v4i02.1464

Toynbee (seorang ahli sejarah), mengatakan bahwa modernitas telah mulai sejak akhir abad ke lima belas ketika orang Barat "berterima kasih bukan kepada Tuhan, tetapi kepada dirinya sendiri karena ia telah berhasil mengatasi kungkungan Kristen abad pertengahan”. Menurut Samuel Huntington, modernitas adalah produk perkembangan ilmu pengetahuan dan teknologi yang membuat manusia mampu membentuk serta mengendalikan alam. Modernitas ditandai dengan proses perubahan yang sangat cepat dengan melibatkan industrialisasi, urbanisasi, dari suatu masyarakat primitif menuju masyarakat berperadaban.

Jika modernisasi merupakan produk perkembangan ilmu pengetahuan, maka Islam menurut Nurcholish Madjid, adalah agama yang sangat modern bahkan terlalu modern untuk zamannya, karena Islam adalah agama yang secara sejati memiliki hubungan organik dengan ilmu pengetahuan dan mampu menjelaskan kedudukan ilmu pengetahuan tersebut dalam kerangka keimanan, maka kaum Muslim hendaknya yakin bahwa Islam bukan saja tidak menentang ilmu pengetahuan, tetapi justru menjadi pengembangannya dan tidak melihat perpisahan antara iman dan ilmu. (Madjid, 2000) Selain itu, kemoderenan kata Nurcholish Madjid adalah relatif sifatnya, sebab terikat oleh ruang dan waktu. Sesuatu yang dikatakan modern dapat dipastikan menjadi kolot (tidak modern lagi) di masa yang akan datang, sedangkan yang modern secara mutlak adalah yang benar secara mutlak, yakni Tuhan. Jadi modernitas berada dalam suatu proses penemuan kebenaran yang relatif menuju penemuan kebenaran yang mutlak, yaitu Allah.

Dengan demikian, dalam memposisikan Islam dengan modernitas yang oleh kebanyakan orang dinilai dikotomis, menurut Nurcholish Madjid mestinya setiap Muslim kembali melihat Islam dalam semangatnya yang lebih dalam. Islam adalah sebuah agama yang mempunyai watak, visi, dan pandangan yang ke arah kemajuan. Islam justru sangat membuka peluang dan memberi tempat pada modernitas. Dalam hal ini masyarakat Islam bisa saja hidup di alam kemodrenan dengan tetap mempertahankan dan memegang teguh nilai-nilai agama yang di anut. Menjadi modern itu tidak harus menghalangi seseorang untuk tetap teguh dan kaffah dalam menjalankan ajaran agamanya. Fraseologinya seseorang bisa menjadi modern dengan tetap setia kepada Islam.

\section{Sekularisasi}

Ide sekularisasi Nurcholish Madjid pertama kali muncul saat beliau berkesempatan memberikan ceramah dalam acara beberapa organisasi mahasiswa pada 3 Januari 1970. (Ismail, 2008) Nurcholish Madjid mengajurkan sekularisasi sebagai 
AT-TAJDID: Jurnal Pendidikan Dan Pemikiran Islam

(p-ISSN: 2548-5784 le-ISSN: 2549-2101)

Vol. (4)(02), (Juli-Desember)(2020), (Halaman)(178-190)

Doi: http://dx.doi.org/10.24127/att.v4i02.1464

sebuah bentuk pembebasan dari segala pandangan-pandangan keliru yang dianggapnya telah mapan, namun Nurcholish Madjid sendiri tidak bermaksud menerima paham sekularisme, bahkan secara tegas ia menolaknya. Memulai anjurannya, Nurcholish Madjid mengatakan; "Sekularisasi tidaklah dimaksudkan sebagai penerapan sekularisme, sebab sekularisme adalah nama sebuah ideologi, sebuah pandangan dunia baru yang tertutup yang dipandang berfungsi sangat mirip dengan agama. Dalam hal ini, yang dimaksudkan ialah setiap bentuk perkembangan yang membebaskan. Proses pembebasan ini diperlukan karena umat Islam, akibat perjalanan sejarahnya sendiri, tidak sanggup lagi membedakan nilai-nilai yang di sangkanya Islami itu, mana yang transendental dan mana yang temporal."

Dari penegasan tersebut, nampaknya Nurcholish Madjid ingin menjelaskan bahwa antara sekularisasi dan sekularisme merupakan dua hal yang berbeda. "Sekularisasi" cenderung kepada sebuah proses, dan "sekularisme" dengan isme-nya merupakan bentuk kepercayaan yang dianggap sebagai padanan agama, seperti yang ada pada dua ideologi besar dunia, sosialisme-komunis dan kapitalisme-sekuler yang dalam prosesnya berusaha melepaskan ketergantungan manusia dari asuhan agama. Dengan mengutip pandapat
Talcot Parson, Nurcholish Madjid menunjukkan bahwa sekularisasi sebagai suatu proses sosiologis, lebih banyak mengisyaratkan pengertian pembebasan masyarakat dari belenggu takhayul dalam beberapa aspek kehidupannya, dan tidak berarti penghapusan orientasi keagamaan dalam norma dan nilai kemasyarakatan.

Secara konkret, menurut cak Nur sekularisasi tidaklah dimaksudkan sebagai penerapan sekularisme dan mengubah kaum Muslimin menjadi sekularis. Tetapi dimaksudkan untuk menduniawikan nilai-nilai yang sudah semestinya duniawi, dan melepaskan umat Islam dari kecenderungan untuk meng-ukhrawi-kannya. Dengan demikian, kesediaan mental untuk selalu menguji dan menguji kembali kebenaran suatu nilai di hadapan kenyataan-kenyataan material, moral ataupun historis, menjadi sifat kaum Muslimin. Lebih lanjut, sekularisasi dimaksudkan untuk lebih memantapkan tugas dunawi manusia sebagai "khalifah Allah di bumi". Fungsi sebagai khalifah Allah itu memberikan ruang bagi adanya kebebasan manusia untuk menetapkan dan memilih sendiri cara dan tindakan-tidakan dalam rangka perbaikan-perbaikan hidupnya di atas bumi ini.

Dalam pengamatan cak Nur, pendekatan animis terhadap bendabenda (dan masalah-masalah duniawi pada umumnya) bersifat serba spiritualistis-animistis. Sebaliknya 
AT-TAJDID: Jurnal Pendidikan Dan Pemikiran Islam (p-ISSN: 2548-5784 le-ISSN: 2549-2101)

Vol. (4)(02), (Juli-Desember)(2020), (Halaman)(178-190)

Doi: http://dx.doi.org/10.24127/att.v4i02.1464

pendekatan Tauhidis terhadap bendabenda dan masalah-masalah duniawi (seharusnya ) bersifat obyektif. Artinya, seorang Tauhidis itu melihat bendabenda (masalah-masalah duniawi) itu menurut apa adanya dan menurut keadaan sebenarnya, (Rasyidi, 1972).

Karena itu, kalau dirunut secara lebih mendalam, Matinya ilmu pengetahuan dalam Islam menurut cak Nur adalah akibat melemahnya kondisi sosial politik dan ekonomi dunia Islam, disebabkan percekcokan yang tidak habis-habisnya dikalangan mereka tidak dalam bidang-bidang pokok melainkan dalam bidang-bidang kecil seperti masalah fiqih dan peribadatan. Perdebatan itu justru diakhiri dengan menutup sama sekali pintu ijtihad, dan mewajibkan setiap orang taqlid kepada para pemimpin atau pemikir keagamaan yang telah ada, yang berakibat mematikan kreatifitas individual dan sosial kaum Muslim.

Dalam hubungan ini, dapatlah kita mengerti mengapa cak Nur menyesalkan keputusan para pemuka Islam untuk menutup pintu ijtihad. Sehingga yang terjadi ialah umat Islam kehilangan kreatifitas dalam kehidupan duniawi, dan mengesankan seolah-olah mereka telah memilih untuk tidak berbuat, dengan kata lain mereka telah kehilangan semangat ijtihad.

Umat Islam sekarang, menurut cak Nur cenderung memahami Islam hanya dari satu sisi ilmu tradisional Islam saja, yakni ilmu fiqih yang hanya membidangi segi-segi formal peribadatan dan hukum, sehingga tekanan orientasinya sangat eksoteristik, mengenai hal-hal lahiriah. Sementara ilmu-ilmu tradisional Islam lain, yakni Falsafah, Kalam, dan Tasawuf masih kalah mendalam dan meluas.

Nampaknya cak Nur menginginkan umat Islam tidak secara parsial memahami Islam dengan hanya menakankan pada masalah fiqhiyah. Apalagi fiqih itu sendiri tak lebih merupakan usaha-usaha ulama dalam mengkontektualisaikan ajaran Islam. Secara logis karena ulama itu sendiri adalah manusia, maka tafsiran ulama tersebut tidak bisa dilepaskan dari sifat kemanuisaannya, dan tak pantas dianggap absolut. Karena mengabsolutkan pikiran ulama - sama artinya mengobsolutkan sesuatu selain Tuhan - secara theologis bisa berakibat pada kesyirikan kepada Allah, Tuhan yang maha absolut. barangkali inilah titik pangkal semangat istilah sekularisasi yang di maksudkan Nurcholis Madjid.

\section{Pemikiran Teologi Islam Inklusif}

Pemikiran Nurcholis Madjid juga membahas mengenai teologi inklusif dan pluralis, menurut Nurcholis madjid Islam adalah sikap pasrah ke hadirat Tuhan, kepasrahan ini menurut Nurcholis Madjid adalah menjadi karakteristik pokok semua agama yang benar, inilah worlview Al-quran, bahwa 
AT-TAJDID: Jurnal Pendidikan Dan Pemikiran Islam (p-ISSN: 2548-5784 le-ISSN: 2549-2101) Vol. (4)(02), (Juli-Desember)(2020), (Halaman)(178-190) Doi: http://dx.doi.org/10.24127/att.v4i02.1464

semua agama yang benar adalah alislam, yakni sikap berserah diri kehadirat Tuhan.

Dalam pemikirannya yakni teologi inklusif, banyak pemikir muslim yang tidak setuju dengan pemikirannya tersebut, bahwa jalan kebenaran dan keselamatan (the truth and salvation) bukan hanya milik kaum muslimin melainkan juga agama yang ada diluar Islam. Orang bisa disebut muslim tanpa harus memeluk agama islam, yang terpenting adalah sikap pasrah terhadap Tuhan.

Menurut Nurcholish Madjid, kita umat islam diperintahkan untuk senantiasa menegaskan bahwa kita semua, penganut kitab suci yang berbeda-beda itu, sama-sama menyembah Tuhan Yang maha Esa, dan sama-sama pasrah (muslimun) kepadaNya. Bangunan Epistemologi teologi inklusif Nurcholis Madjid diawali dengan tafsir al Islam yang berarti pasrah.

Teori teologi Inklusif dari Nurcholis Madjid ini, berupaya mendekontruksi makna Islam yang sesungguhnya, Islam sebagai sebuah agama (Ad-din) yang sudah diridhai Allah sebagai agama yang benar, didekontruksi maknanya sehingga agama yang benar disisi Tuhan bukanlah agama Islam saja, akan tetapi semua agama disisi Tuhan sama kedudukannya, dan orang yang pasrah (al-Islam) kepada ajarannya ia akan masuk surga, baik ia beragama Kristen, Yahudi, Budha, Hindu dsb.
Menurut Nurcholis, ada tiga sikap dialog agama yang diambil. Yaitu, pertama, sikap eksklusif dalam agama lain (agama-agama yang lain adalah jalan yang salah, yang menyesatkan bagi umatnya). Kedua, sikap inklusif (agama-agama lain adalah bentuk implisit agama kita), ketiga sikap pluralis yang bisa terekpresi dalam macam-macam rumusan.

\section{Pemikiran cak Nur dalam pandangan para kritikus}

Gagasan yang dilontarkan oleh Nurcholish Madjid memang dianggap sebagai suatu ide pembaruan yang begitu luar biasa dalam kancah pemikiran keIslaman. Namun di sisi lain, idenya tersebut juga menimbulkan suatu polemik yang berkesinambungan dikalangan elit intelektual Muslim. Diantara gagasan idenya yang cukup kontroversial yaitu mengenai ungkapannya tentang sekularisasi, cak Nur menyatakan bahwa: "Islam sebenarnya dimulai dengan proses sekularisasi dan tauhid merupakan pangkal tolak sekularisasi secara besarbesaran." Gagasan tersebut memang menjadi landasan pacu dalam pembaruan pemikiran Nurcholish Madjid, akan tetapi hal ini pula yang memunculkan kontroversi mendalam dari beberapa kalangan intelektual, seperti H.M Rasyidi, Faisal Ismail.

Pertama, penulis akan memaparkan pandangan dan kritikan dari H.M Rasyidi: dalam pandangan H.M Rasyidi, bahwa apa yang digambarkan Nurcholish Madjid 
AT-TAJDID: Jurnal Pendidikan Dan Pemikiran Islam

(p-ISSN: 2548-5784 le-ISSN: 2549-2101)

Vol. (4)(02), (Juli-Desember)(2020), (Halaman)(178-190)

Doi: http://dx.doi.org/10.24127/att.v4i02.1464

tentang tauhid sebagai sekularisasi besarbesaran, yakni tidak memuja selain Tuhan, dan segala benda di dunia ini harus kita selidiki dan dipergunakan. Seakan-akan menunjukkan bahwa manusia di dalam dunia ini hanya menghadapi dua alternatif yaitu apakah ia harus menyembah Allah saja sebagai orang bertauhid, atau menyembah segala yang ada di dunia ini sebagai animis. Padahal persoalannya tidaklah demikian adanya, manusia pada dasarnya tidak hanya berhadapan dengan Allah dan alam saja, tetapi ia juga berhadapan dengan jiwanya sendiri. Meskipun ia menyelidiki sesuatu dalam alam, sesungguhnya baru sedikit sekali yang diketahui oleh manusia. Dan hal itu juga tidak boleh dilakukan dengan terlepas dari Tuhan atau menjadi sesuatu yang otonom., karena segala sesuatu yang dilakukan manusia adalah dalam kerangka pengabdian kepada Tuhan. Selain itu, pada zaman teknologi ini sesungguhnya manusia dihadapkan pada satu persoalan pokok, yakni: persoalan mana yang baik aku lakukan dan mana yang tidak baik untuk dilakukan. Disinilah letaknya kepentingan agama di dunia ini. Agama bukan hanya untuk akhirat belaka, tetapi juga untuk dunia. Akhirat hanya merupakan akibat dari hukum agama di dunia ini. (Rasyidi, 1972).

Kedua, pandangan dan kritikan Faisal Ismail. Secara ringkas, beliau mengkritik bahwa konsep Nurcholish Madjid yang memisahkan antara sekularisasi dengan sekularisme merupakan suatu bentuk kekacauan berpikir (confusion of mind).
Seperti yang penulis paparkan diatas, Nurcholish Madjid beranggapan bahwa antara sekularisasi dan sekularisme merupakan dua hal yang berbeda. "Sekularisasi" cenderung kepada sebuah proses, dan "sekularisme" dengan ismenya merupakan bentuk kepercayaan yang dianggap sebagai padanan agama, seperti yang ada pada dua ideologi besar dunia, sosialisme-komunis dan kapitalismesekuler yang dalam prosesnya berusaha melepaskan ketergantungan manusia dari asuhan agama. Dengan mengutip pandapat Talcot Parson, Nurcholish Madjid menunjukkan bahwa sekularisasi sebagai suatu proses sosiologis, lebih banyak mengisyaratkan pengertian pembebasan masyarakat dari belenggu takhayul dalam beberapa aspek kehidupannya, dan tidak berarti penghapusan orientasi keagamaan dalam norma dan nilai kemasyarakatan.

Padahal, menurut Faisal Ismail jika dilihat dari sisi semantik, konsep cak Nur yang memisahkan antara konsep sekularisasi dan sekularisme adalah hal yang absurd dan merupakan suatu semantic confusion. Secara tegas, Faisal Ismail menyimpulkan bahwa sekularisasi merupakan proses pengaplikasian dan praktik-praktik penerapan sekularisme. Atau, proses dan praktik-praktik penerapan sekularisme dalam tatanan kehidupan masyarakat disebut sekularisasi. Tingkat intensitas sekularisasi dalam tatanan kehidupan masyarakat akan mempengaruhi tingkat intensitas perkembangan sekularisme dalam kehidupan mereka. Sebaliknya, jika 
AT-TAJDID: Jurnal Pendidikan Dan Pemikiran Islam

(p-ISSN: 2548-5784 le-ISSN: 2549-2101)

Vol. (4)(02), (Juli-Desember)(2020), (Halaman)(178-190)

Doi: http://dx.doi.org/10.24127/att.v4i02.1464

pelaksanaan sekularisasi kurang intensif dalam masyarakat, maka perkembangan sekularisme kurang intensif pula. Secara ringkas, Faisal Ismail ingin menegaskan bahwa sekularisasi pasti menuju ke sekularisme. Tidak seperti yang dipaparkan oleh cak Nur yang memisahkan kedua konsep tersebut. (Ismail, 2008)

Sebetulnya masih ada banyak kritikan yang dilontarkan oleh para kritikus tersebut. Namun disini, penulis hanya memaparkan sebagian saja dari gagasangagasan cerdas para kritikus di atas dengan asumsi kritikan tersebut sudah cukup sedikit mewakili dari pandanganpandangan pokok mereka.

\section{KESIMPULAN}

Sebagai seorang tokoh yang dilahirkan di lingkungan yang sangat kental dengan nilai-nilai ajaran agama Islam serta mendapatkan pendidikan barat yang modern dan sekuler, telah membuat sosok Nurcholis Madjid menjadi seorang yang benar-benar ampuh dan mumpuni dalam memadukan khazanah Islam klasik dan khazanah keilmuan modern. Hal ini pula yang menjadikan cak Nur sebagai seorang figur yang sangat dikagumi baik oleh para gurunya, rekan dan mahasiswanya. Beliau tidak hanya merupakan seorang tokoh yang dekat dengan iman, tapi juga merupakan tokoh yang sangat dekat dengan kebebasan berpikir. Gagasangagasannya begitu memukau, gaya penyampaiannya begitu dramatis dan sangat artikulatif. Pidatonya di Taman
Ismail Marzuki pada era 1970-an dengan menggagas mengenai pembaruan pemikiran Islam telah mengantarkannya menjadi seorang Pembaru pemikiran Islam kontemporer di Indonesia. Kendatipun gagasan-gagasannya selalu mendapat kritikan tajam baik dari guru dan koleganya, beliau tetap terbuka dan selalu memberi apresiasi tinggi akan kritikan tersebut.

Kini cak Nur memang telah tiada, namun karya-karya monumentalnya akan terus menjadi warisan berharga bagi kemajuan pemikiran Islam di Indonesia ke depan, dan semoga sosok-sosok Nurcholish muda baru akan segera lahir dan bangkit untuk meneruskan apa yang telah diperjuangkannya selama ini, amin. Wallahu A'lam bi Ash Shawwab.[]

\section{DAFTAR PUSTAKA}

Hadi, S. (1990). Metodologi Research. Andi. Yogyakarta. Theo Huijbers Filsafat Hukum. Kanisius. Yogyakarta.

Ismail, F. (2008). Sekularisasi: membongkar kerancuan pemikiran Nurcholish Madjid. Pesantren Nawesea Press.

Lexy, J. M. (2010). Qualitative research methodology. Bandung: Remaja Rosdakarya.

Qodir, Z. (2006). Pembaharuan pemikiran Islam: wacana dan aksi Islam Indonesia. Pustaka Pelajar.

Rasyidi, M. (1972). Koreksi Terhadap Drs. Nurcholis Madjid Tentang Sekularisasi. Bulan Bintang.

Nurcholish Madjid, 2020 Islam Doktrin dan Peradaban; Sebuah telaah kritis tentang masalah keimanan, kemanusiaan, dan kemodernan, (Jakarta: Yayasan Wakaf Paramadina. 
AT-TAJDID: Jurnal Pendidikan Dan Pemikiran Islam (p-ISSN: 2548-5784 |e-ISSN: 2549-2101)

Vol. (4)(02), (Juli-Desember)(2020), (Halaman)(178-190)

Doi: http://dx.doi.org/10.24127/att.v4i02.1464

http://id.wikipedia.org/wiki/Nurcholish Madjid. Di akses pada tanggal 07 Mei 2020.

http://www.doepatu.co.cc/2011/02/arahpembaharuan-pemikirannurcholis.html. Di akses pada tanggal 07 Mei 2020. http://rullypattimahu.wordpress.com/201

0/07/30/nurcholish-madjid-danpembaruan-islam. Di akses pada tanggal 07 Mei 2020. 